DOI 10.25205/2541-9447-2018-13-4-106-110

\title{
Complex for Nanoscale Researches by Using TERS, SNOM, BLS, and SPM Techniques
}

\author{
J. Jersch, S. Demokritov \\ Institute of Applied Physics, University of Muenster \\ Muenster, Germany
}

Abstract

We will focus in on our recent developed Complex for nanoscale research with TERS (Tip Enhanced Raman Scattering), SNOM (Scanning Nearfield Optical Microscopy), BLS (Brillouin Light Scattering) and SPM (Scanning Probe Microscopy) techniques, designed in Laboratory of Nonlinear Magneto dynamic (Head Prof. Dr. S. O. Demokritov) in Institute for Applied Physics and Center for Nonlinear Science, University of Muenster. The Complex, built on base of SPM NTEGRA Spectra C (NTMDT) and 6-pass Tandem-Fabry-Perot-Interferometer (JRS Scientific Instruments), designed for nanotechnology research, mainly on spintronic nanostructures.

Keywords

nanotechnology, scanning probe microscopy, Raman spectroscopy, spin dynamics

For citation

Jersch J., Demokritov S. Complex for Nanoscale Researches by Using TERS, SNOM, BLS, and SPM Techniques. Siberian Journal of Physics, 2018, vol. 13, no. 4, p. 106-110. DOI 10.25205/2541-9447-2018-13-4-106-110

\section{Комплекс для наноисследований с использованием методов зондово-усиленного комбинационного рассеяния (TERS), сканирующей ближнеполевой оптической микроскопии (SNOM), спектроскопии Бриллюэновского рассеяния (BLS) и сканирующей зондовой микроскопии (SPM)}

\author{
И. Г. Ерш, С. О. Демокритов \\ Институт прикладной физики, Университет г. Мюнстера \\ Мюнстер, Германия
}

Аннотация

Мы сосредоточимся на нашем недавно разработанном Комплексе для наноисследований с использованием методов зондово-усиленного комбинационного рассеяния (TERS), сканирующей ближнеполевой оптической микроскопии (SNOM), спектроскопии Бриллюэновского рассеяния (BLS) и сканирующей зондовой микроскопии (SPM), разработанном в лаборатории нелинейной магнитодинамики (зав. проф., д-р С. О. Демокритов) в Институте прикладной физики университета г. Мюнстера. Комплекс, построенный на основе многофункционального СЗМ ИНТЕГРА Спектра С компании НТМДТ (SPM NTEGRA Spectra C) и 6-проходного ФабриПеро-тандем-интерферометра (JRS Scientific Instruments), предназначен для нанотехнологических исследований, в основном на наноструктурах для спинтроники.

Ключевые слова

нанотехнологии, сканирующая зондовая микроскопия, рамановская спектроскопия, спиновая динамика

\section{Experimental}

The NTEGRA Spectra (NT-MDT) ${ }^{1}$ successfully integrate SPM techniques with optical microscopy and spectroscopy techniques. A number of basic and advanced SPM modes (AFM, MFM,

\footnotetext{
${ }^{1}$ https://www.ntmdt-si.com/products/afm-raman-nano-ir-systems/ntegra-spectra-ii
} 
STM, Kelvin, SThM, SNOM etc.) are supported providing extensive information about the sample surface physical properties. Integration of SPM with confocal Raman / fluorescence microscopy provide the widest range of additional information about the sample. Simultaneously measured AFM, MFM, SThM and Raman maps of exactly the same sample area provide complementary information about sample physical properties (Topography, Magnetic, Temperature) and chemical composition (Raman).

Furthermore, NTEGRA Spectra with the help of Tip Enhanced Raman Scattering (TERS) allows carrying out spectroscopy / microscopy with nanometer scale resolution. Specially prepared AFM or SNOM probes (nanoantennas) can be used for TERS to enhance and localize light at the nanometer scale area near the tip apex.

The related to Raman Technique, BLS Technique (Scattering of Photons on Magnon quanta in our structures) based on Multi-Pass-Tandem-Fabry-Perot Interferometer ${ }^{2}$ is an established method for studying magnetization dynamics in magnetic layer systems, with very high optical quality (resolution in sub-MHz region, damping of higher harmonics better then $10^{6}$ ). This part of the Complex allows magnon (spin wave) detection with sub micrometer resolution in standard light microscopy design. In combination with SNOM probe the resolution of approximately $50 \mathrm{~nm}$ is achieved. The probe used is an industrial (WITec GmbH, Nascatec GmbH, Germany, or NTMDT SNOM Tip ${ }^{3}$ ) silicon cantilever based hollow pyramidal aluminum tip with a small $(50 \mathrm{~nm}$ or $100 \mathrm{~nm})$ aperture at the apex to focus the input laser light.

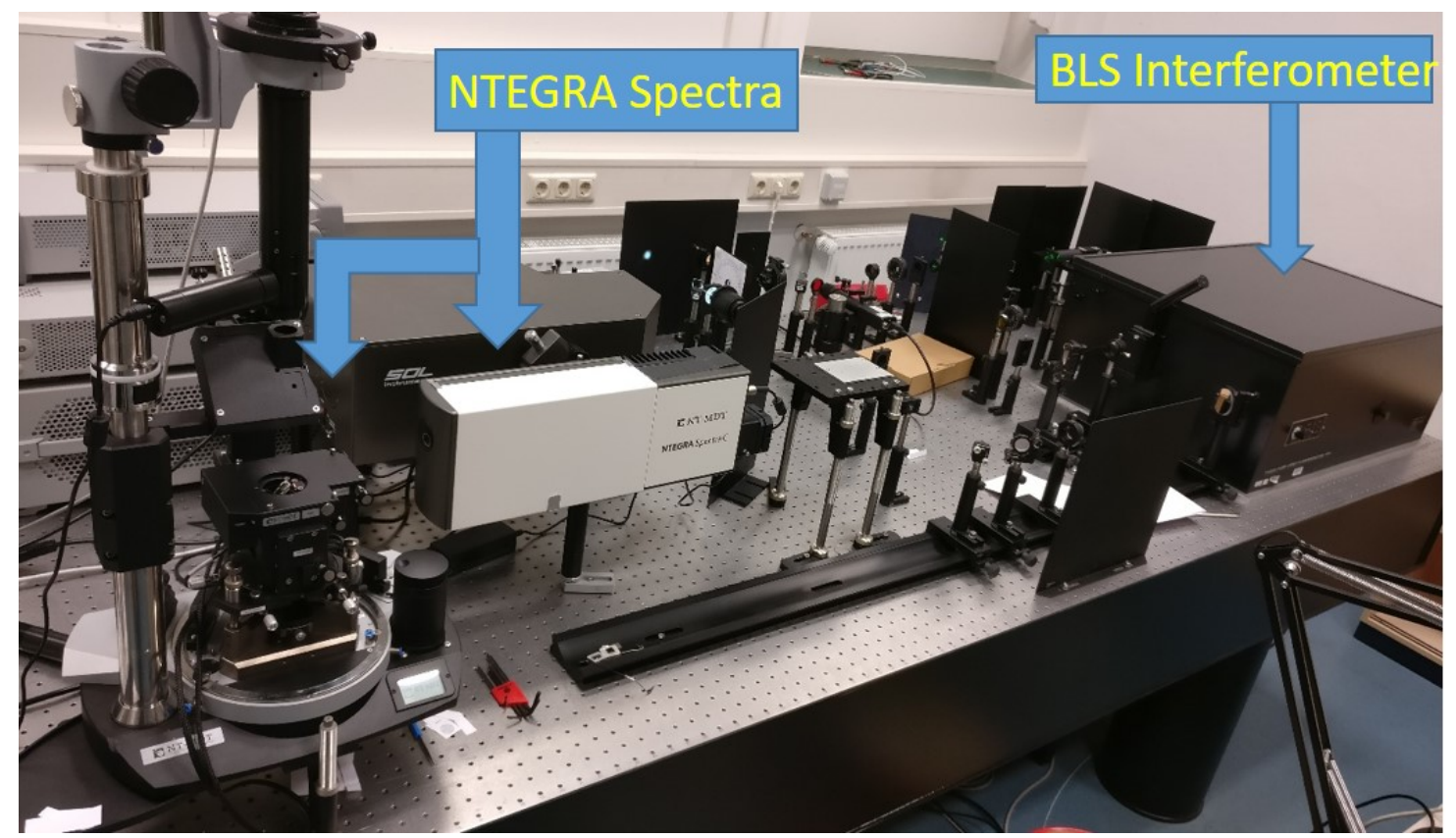

Fig. 1. The Complex for nanoscale research setup on an optical table (table dimension $3000 \times 1200 \mathrm{~mm}$ )

Furthermore, we modified by FIB technique this SNOM tip, as shown in Fig. 2. A nanoscale Al features on the apex of the pyramidal tip allows higher sensitivity due to tip enhancement and improve the AFM and optical properties of the tip in TERS and SNOM.

\footnotetext{
${ }^{2}$ JRS Scientific Instruments Tandem-Fabry-Perot Interferometer TFP-1, Operators Manual, www.jrs-si.ch (2001).

${ }^{3}$ http://www.ntmdt-tips.com/products/group/snom-cantilevers-new
} 


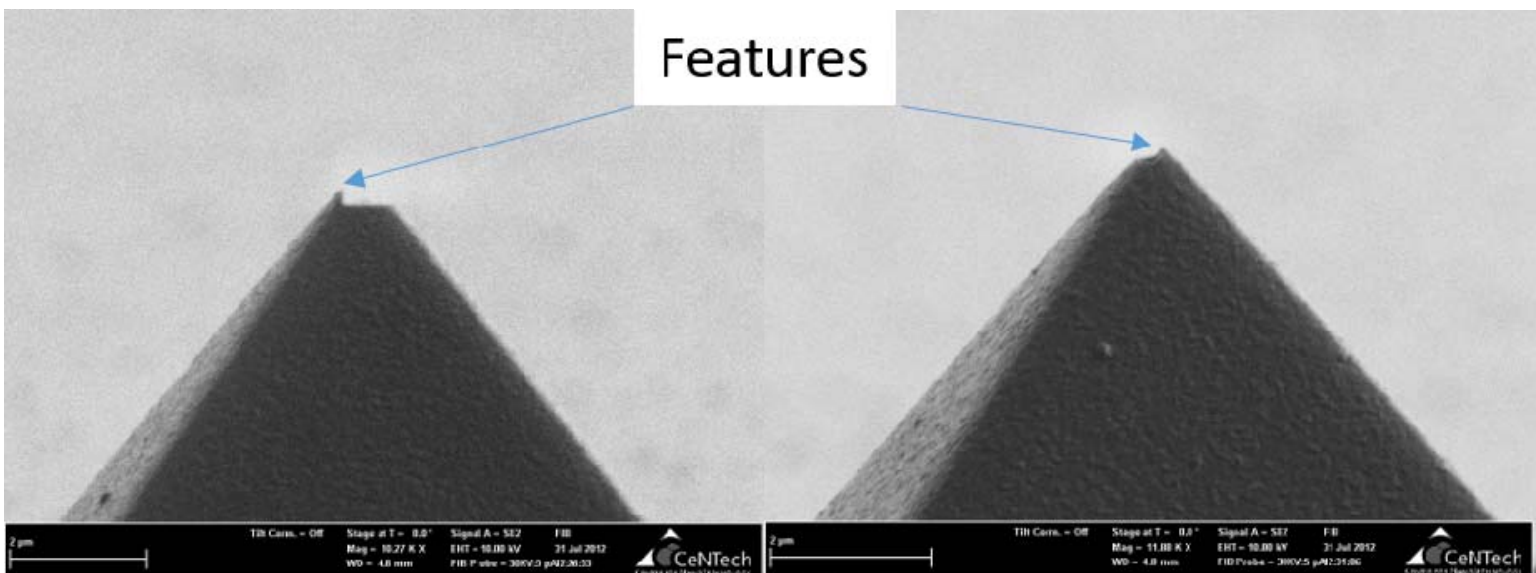

Fig. 2. Modified pyramidal SNOM Tips with features (Apex radius of the features approx. $30 \mathrm{~nm}$ )

\section{Applications}

Further, we present some measurements carried out on the device. For example [1], we study organic field-effect transistors (OFETs) (essential components for the realization of recyclable integrated circuits). Fig. 3 shows Raman spectra on pentacene (this highly conjugated compound is an organic semiconductor) islands of organic FETs. The signal at approx. $5001 / \mathrm{cm}$ is from the $\mathrm{Si}$ base, around $15001 / \mathrm{cm}$ - pentacene.

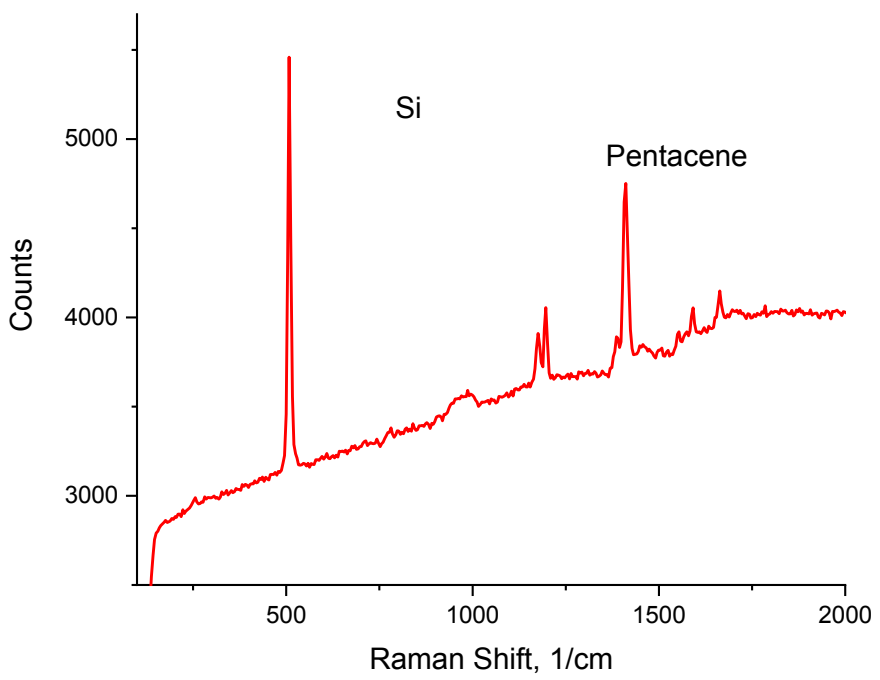

Fig. 3. Raman signal on organic pentacene island

In one of the first application [2], we report on two-dimensional mapping of edge modes in elliptical magnetic elements. Elliptical elements with lateral dimensions of $1.3 \times 2.4 \mu \mathrm{m}^{2}$ generated by e-beam lithography and ion etching from a $20 \mathrm{~nm}$ thick film of $\mathrm{Ni}_{80} \mathrm{Fe}_{20}$ (Permalloy) were located on top of a microwave microstrip transmission line used for the excitation of spin dynamics. The static uniform magnetic field $H$ is applied along the long axis of the ellipses and is perpendicular to the dynamic magnetic field $h$ as shown in the image below Fig. 4. 


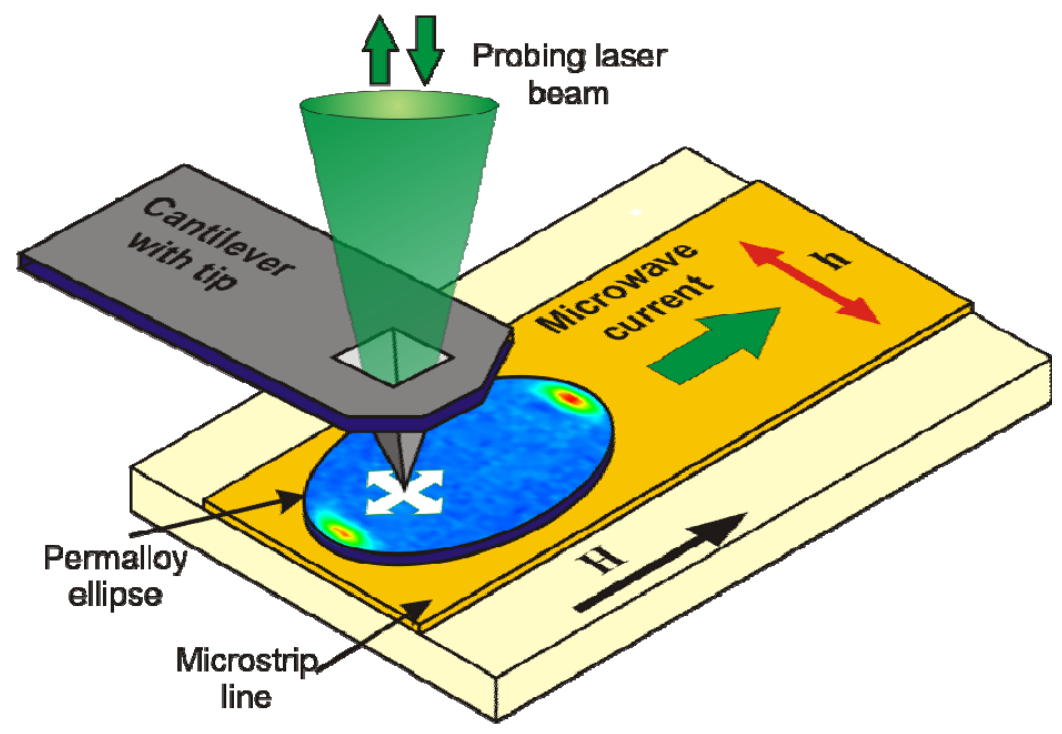

Fig. 4. Experimental setup with pyramidal SNOM-TERS tip

We show (for the first time) that the spatial resolution of this technique is below $55 \mathrm{~nm}$ (Fig. 5). Using the approach we found that with increasing applied magnetic field, $H$, the mode width scales as $1 / H$ in agreement with a straightforward qualitative model and can be as small as $85 \mathrm{~nm}$.

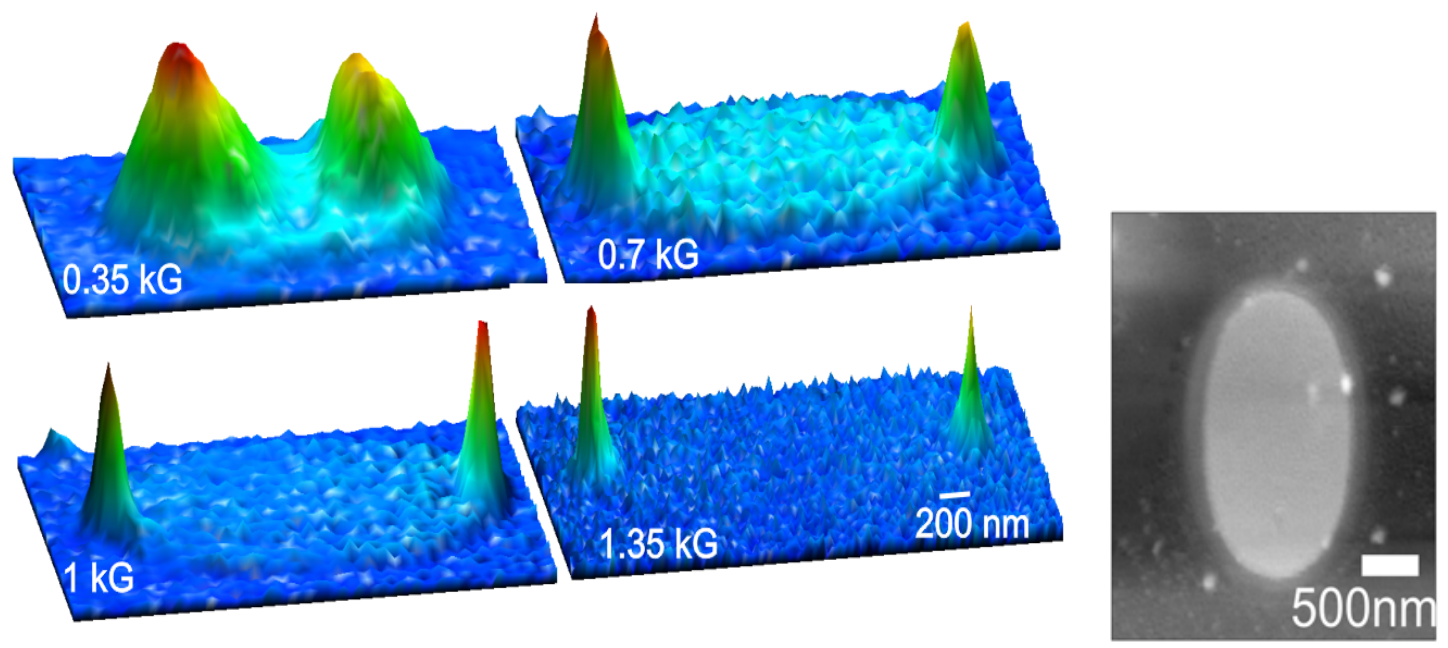

Fig. 5. Successive images of the magnon edge modes intensity in increasing magnetic field and the simultaneously topography scan of the ellipse

\section{Conclusion}

A successful demonstration of modified to a research complex, commercially available sophisticated equipment, was performed. It succeeded with a SNOM tip, inherently having a low optical transmission to detect weak Raman scattering on magnons. A high spatial and spectral resolution as well as optical sensitivity thanks to TERS effect shows, that the complex is a promising tool for 
a wide field of applications in nanotechnology. The complex can also form a basis for sustainable research in various modern physical branches.

\section{References}

1. Deyang Ji, Johann Jersch, and Harald Fuchs. Holey Contacts: A New Approach to Enhance Charge Injection through Low-Cost Nanopore-Structured Silver Electrodes in Bottom-Gate Bottom-Contact (BGBC) Organic Field-Effect Transistors. Adv. Electron. Mater., 2016, 1600215, p. 1-7. https://doi.org/10.1002/aelm.201600215

2. Jersch J., Demidov V. E., Fuchs H., Rott K., Krzysteczko P., Münchenberger J., Reiss G., Demokritov S. O. Mapping of localized spin-wave excitations by near-field Brillouin light scattering. Appl. Phys. Lett., 2010, vol. 97, p. 152502.

\section{Information about the Authors / Сведения об авторах}

Johann Jersch, Institute of Applied Physics, University of Muenster (2/4 Correns Str., DE48149 Muenster, Germany)

Ерш Иван Г., Институт прикладной физики, Университет г. Мюнстера (Корренс-Штрассе, 2/4, Мюнстер, 48149, Германия)

jersch@uni-muenster.de

Sergey Demokritov, Institute of Applied Physics, University of Muenster (2/4 Correns Str., DE48149 Muenster, Germany)

Демокритов Сергей О., Институт прикладной физики, Университет г. Мюнстера (КорренсШтрассе, 2/4, Мюнстер, 48149, Германия)

demokrit@uni-muenster.de 